$$
\text { , }
$$ 


\section{NBSIR $79-1600$}

,'

\section{RADIO FREQUENCY LIQUID LEVEL GAUGING IN PROPANE TANK CAR SAFETY TESTS - A FEASBBLLITY STUDY}

J. D. Siegwarth

Thermophysical Properties Division

National Engineering Laboratory

National Bureau of Standards

Boulder, Colorado 80303

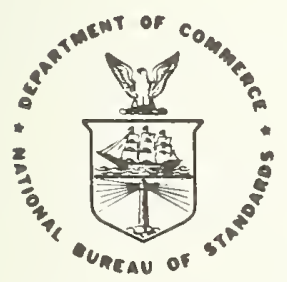

U.S. DEPARTMENT OF COMMERCE, Juanita M. Kreps, Secretary Sidney Harman, Under Secretary Jordan J. Baruch, Assistant Secretary for Science and Technology

NATIONAL BUREAU OF STANDARDS, Ernest Ambler, Director 

CONTENTS

ABSTRACT $\ldots \ldots \ldots \ldots \ldots \ldots \ldots \ldots \ldots \ldots \ldots \ldots \ldots \ldots \ldots \ldots \ldots \ldots$

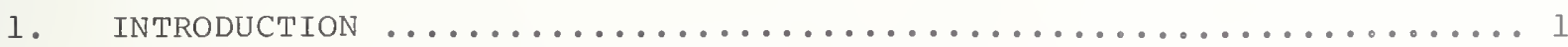

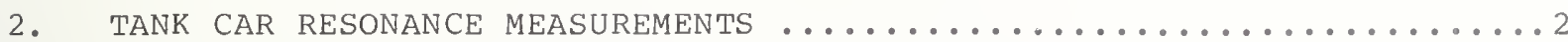

3. LiQuid LEVEL MEASUREMENTS IN A SMALL hORIZONTAL CYLINDRiCAL TANK....4

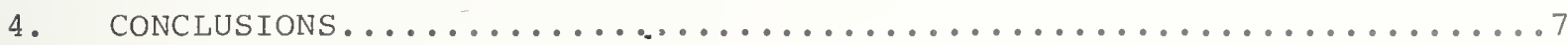

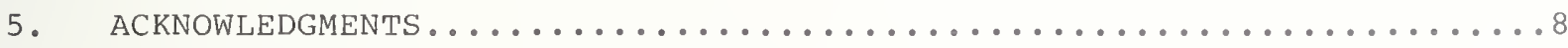

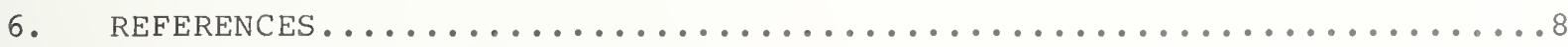

APPENDIX 1. Resonance Frequency Measurements of Model Tank Car.....9 
RADIO FREQUENCY LIQUID LEVEL GAUGING IN PROPANE TANK CAR SAFETY TESTSA FEASIBILITY STUDY

\author{
J. D. Siegwarth \\ Thermophysical Properties Division \\ National Engineering Laboratory \\ National Bureau of Standards \\ Boulder, Colorado 80303
}

\begin{abstract}
Selected radio frequency ( $r f$ ) resonances of an empty 30,300 liter ( 8000 gallon) tank car have been measured to determine whether rf can be used to gauge the propane liquid levels during tank car fire safety tests. The change of resonant frequencies of a small horizontal cylindrical tank as a function of liquid volume has been tested in order to estimate the precision to which the amount of propane in a tank car can be measured. The technique is applicable to routine tank car gauging.
\end{abstract}

Key words: Level gauging, propane, radio frequency 
On July 28, 1973 and again on December 5, 1973 full sized propane tank cars containing $1.25 \times 10^{5} \mathrm{~L}(33,000 \mathrm{gal})$ of liquid propane were subject to an all enveloping fire. These tests were part of an RPI-AAR Tank Car Safety Research and Test Program [1] ultimately aimed at reducing the probability of tank car rupture in accidents with associated fires.

The tank cars tested were instrumented so that pressure, various temperatures, safety valve performance and quantity of liquid remaining in the tank could be measured while the car is subjected to a fire. Much of this instrumentation failed early in the test. For instance, none of the level measuring devices developed for these tests gave any usable information in either test. The level devices are aescribed in the report only as a resistance gauge, a hot wire gauge and a thermistor gauge.

An rf (radio frequency) resonance type level system should function more reliably in the extreme environment of these fire tests since the gauge is not dependent on the thermal or any other property of the sensor. The tank size and shape and the dielectric constant of the fluid within are the relevant physical parameters. The shape and size of the small antenna required is unimportant and only a single coaxial lead (probably cooled) is sufficient.

Details of rf gauging have been presented in an earlier report [2]. Briefly, closed conducting cavities of any shape resonate at discrete frequencies above some cutoff frequency dictated by the cavity size and shape. These resonant frequencies correspond to standing magnetic and electric field patterns inside the tank generated by current patterns in the walls [3]. These patterns remain in fixed positions in the walls but vary in magnitude at the resonant frequency. The actual number of resonant frequencies is infinite. Only the frequencies immediately above the cutoff are well separated. The electric fields associated with these modes are sensitive to the dielectric constant, $\varepsilon$, of the vessel volume such that

$$
f_{n} \propto \varepsilon^{-\frac{1}{2}}
$$

where $f_{n}$ is the frequency of the $n$th mode. If the vessel is only partly filled with a fluid of higher $\varepsilon$, resonant modes still exist though the field patterns are altered from the case of uniform $\varepsilon$. Whereas the mode frequencies of a geometric vessel such as a sphere or a cylinder can be calculated analytically for uniform dielectric constant, this is no longer true for a tank only partially filled. For a partially filled tank however, the resonant frequency of a mode changes monotonically between the two frequencies dictated by the completely empty $\varepsilon$ and the completely full $\varepsilon$.

One of the methods for measuring the rf resonances of a tank consists of inserting a small loop antenna into the tank and driving the airtenna with an rf generator while monitoring the power reflected from the antenna. The reflected power decreases at the frequency of a resonance. This frequency can be converted to a tank level reading of the tank contents with an accuracy dependent upon the resonant line width, the accuracy with which the resonant frequency can be measured, and the accuracy of the calibration of the tank gauge in terms of frequency as a function of level height.

Some preliminary measurements have been made to obtain information on the resonance line width or " $Q$ " of a tank car and to estimate the resolution in a measurement of liquid volume. The ratios of the resonant frequencies are independent of the size of vessels of the same shape. This fact is used in this work to model the tank car for some of the tests. 
A $3 \times 10^{5} \mathrm{~L}(8000 \mathrm{gal})$ tank car used to transport diesel oil was selected for a study of the line widths of the rf resonance modes of a tank car. This tank car has a diameter of $2.979 \mathrm{~m}(78 \mathrm{in.})$ for a length of $9.72 \mathrm{~m}(31.94 \mathrm{ft})$. The tank is longer because the ends approximate spherical sections. The radius of curvature of the ends is so large that each add only about $20 \mathrm{~cm}$ maximum to the tank length at the centerline. A cylindrical dome approximately one meter in diameter and $1 / 2$ meter high is located on the top center of the tank. This dome communicates with the interior of the tank through a hole cut through the top of the tank. A $2.5 \mathrm{~cm}$ diameter valve stem extends vertically along a diameter of the tank up into the dome about $30 \mathrm{~cm}$ from the center of the tank. There is access into the dome through a hatch in the top center.

A loop antenna was mounted on a curved rectangular aluminum plate clamped across the approximately $55.9 \mathrm{~cm}$ (22 in) diameter hole in the tank shell inside the dome. The plate was mounted with its length perpendicular to the centerline of the tank. The loop antenna was mounted in a plane perpendicular to the tank centerline. Three different loops were used. The first was $12.7 \mathrm{~cm}$ square, the second was $28 \mathrm{~cm}$ diameter circle and the last was a $21.5 \mathrm{~cm}$ diameter circle. The antennas were formed by bending a $1.5 \mathrm{~mm}$ diameter copper wire to the desired shape.

The resonant frequencies were measured by placing the frequency marker of an rf sweep unit near the line to be measured, then switching the sweep unit to the continuous wave mode. The position of the scope trace could be easily placed at the minimum vertical position corresponding to maximum rf power absorption. The frequency was measured with a frequency counter.

The $Q$ (resonant frequency divided by the resonant line width) was estimated by measuring the half power point frequencies which were deterinined by observing the rf power absorption level on a scope trace. A lower limit on the estimated $Q$ is 1600 . The longest antenna was employed for this measurement and saturation effects broaden the line. The frequency of the absorption peak (i.e. center of the line) could be easily measured to one part in $10^{4}$.

The rf power input to the tank at a resonant frequency is increased when the antenna size is increased. A large antenna can become part of the resonant structure of the tank thereby shifting the resonant frequencies. The largest antenna used in this tank produced a small but detectable shift in the resonant frequencies so the results of the smaller circular antenna are used to compare with calculated resonant frequencies.

The tank resonances were calculated from the solution to Maxwells equations for a cylindrical vessel. The tank car was assumed to be a perfect cylinder $1.979 \mathrm{~m}$ diameter by $10.09 \mathrm{~m}$ long. The resonant frequencies calculated are shown in table I and the modes are identified ${ }^{3}$. The outside length of the tank was reduced by $3.6 \mathrm{~cm}$ to account for end thickness and shape to arrive at the inside length. The mode frequencies are not strongly dependent on the length of the tank. The measured resonant frequencies are shown in the last column. No attempt has been made to identify the experimental modes though for a few resonances identification can be inferred. Modes are identified as TM or TE followed by three digits. Reference 3 describes this notation in detail and includes diagrams of the electric field configurations associated with some lower modes. 
Table I. Resonant frequencies of a $3 \times 10^{4} \mathrm{~L}(8000 \mathrm{gal})$ tank car using a $21.5 \mathrm{~cm}$ diameter loop antenna perpendicular to the tank centerline.

\begin{tabular}{|c|c|c|}
\hline Mode & $\begin{array}{l}\text { Calculated } \\
\text { Frequency }\end{array}$ & $\begin{array}{c}\text { Measured } \\
\text { Frequencies }\end{array}$ \\
\hline $\begin{array}{ll}\mathrm{TE} & 111 \\
\mathrm{TE} & 112 \\
\mathrm{TE} & 113\end{array}$ & $\begin{array}{l}90.06 \mathrm{MHz} \\
93.67 \\
99.39\end{array}$ & $\begin{array}{l}89.87 \mathrm{MHz} \\
91.87 \\
99.35\end{array}$ \\
\hline $\begin{array}{ll}\text { TE } & 115 \\
\text { TM } & 010 \\
\text { TM } & 011 \\
\text { TM } & 012\end{array}$ & $\begin{array}{l}115.81 \\
116.04 \\
117.0 \\
119.79\end{array}$ & $\begin{array}{l}116.05 \\
118.60\end{array}$ \\
\hline TE 116 & 125.87 & 125.87 \\
\hline $\begin{array}{ll}\text { TE } & 117 \\
\text { TM } & 015\end{array}$ & $\begin{array}{l}136.8 \\
137.8\end{array}$ & $\begin{array}{l}137.31 \\
138.24\end{array}$ \\
\hline $\begin{array}{ll}\mathrm{TM} & 016 \\
\mathrm{TE} & 211 \\
\mathrm{TE} & 118 \\
\mathrm{TE} & 212\end{array}$ & $\begin{array}{l}146.35 \\
148.1 \\
148.2 \\
150.3\end{array}$ & $\begin{array}{l}147.63 \\
148.39 \\
148.77\end{array}$ \\
\hline TE 213 & 153.94 & $\begin{array}{l}154.19 \\
154.98\end{array}$ \\
\hline $\begin{array}{ll}\text { TM } & 017 \\
\text { TE } & 214 \\
\text { TE } & 119\end{array}$ & $\begin{array}{l}155.85 \\
158.91 \\
160.58\end{array}$ & $\begin{array}{l}157.71 \\
159.24 \\
161.26 \\
161.41\end{array}$ \\
\hline $\begin{array}{ll}\text { TE } & 215 \\
\text { TM } & 018\end{array}$ & $\begin{array}{l}165.03 \\
166.14\end{array}$ & $\begin{array}{l}165.28 \\
168.4\end{array}$ \\
\hline $\begin{array}{ll}\mathrm{TE} & 216 \\
\mathrm{TE} & 111\end{array}$ & $\begin{array}{l}172.24 \\
173.15\end{array}$ & 176.45 \\
\hline $\begin{array}{ll}\text { TM } & 109 \\
\text { TE } & 217\end{array}$ & $\begin{array}{l}177.09 \\
180.38\end{array}$ & $\begin{array}{l}179.11 \\
180.85\end{array}$ \\
\hline
\end{tabular}

The modes are identified in the first column and the frequencies calculated for a $1.979 \mathrm{~m}$ diameter by 10.09 meter long cylindrical cavity are given in the second column. Measured frequencies for the actual tank car are listed in the third column. The mode identifications are tentative. 
The experimental and calculated values of the resonant frequencies differ slightly. This is expected since resonance measurements on a small scale model of a tank (Appendix l) show that the valve stem, running on a diameter through the center of the tank, does shift the resonant frequencies slightly. The shifts in frequency of the various TE modes from the values calculated for the tank car are generally in the same direction as observed in the model tank though some of the shifts are relatively larger. No measurements were made to determine whether any TM modes were present or whether the extra experimental lines in the vicinity of the calculated mode lines result from removal of TE mode degeneracies. Though only one TM at most appeared to be present in the model tank, several features of the tank car differed from the model which could lead either to degeneracy removal or to coupling to the TM modes. For instance, the hole in the tank shell is relatively larger than the hole in the model and was not covered completely by the plate on which the antenna was mounted. The valve rod extends through the shell of the tank, without touching, up into the dome so that the dome is electrically coupled to the tank. Effects due to the curved ends of the tank were not investigated but are assumed small.

The experimental frequencies agree quite well with the calculated values for an ideal cylindrical vessel $1.979 \mathrm{~m} \mathrm{I.D.} \mathrm{by} 10.09 \mathrm{~m}$ long. Small shifts in resonant frequencies can probably be accounted for by the presence of the valve stem (Appendix I). Protrusions such as the valve stem do not significantly alter the resonant frequencies and the $Q$ is large.

\section{LIQUid LEVEL MEASUREMENTS IN A SMALL HORIZONTAL CYLINDRICAL TANK}

As noted above, the frequency to liquid level relationship, if expressed as a ratio of any mode frequency to either the full or empty mode frequency, is independent of tank size. To estimate how precisely propane levels, i.e., the amount of propane, can be gauged using rf, resonant frequencies as a function of liquid level were measured in a $28.5 \mathrm{~cm}$ diamter $\mathrm{x}$ $32.7 \mathrm{~cm}$ long cylindrical tank. For safety, kerosene, with a dielectric constant of about 2.1, was used as the dielectric fluid. Since the dielectric constant of propane is around 1.6 , level measurements with kerosene should be more precise. Values of the frequency as a function of liquid volume are listed in table II for frequencies below $1000 \mathrm{MHz}$. Three of the mode frequencies are shown as a function of liquid volume per unit length in figure 1. The modes with electric fields vertical are much more strongly perturbed by the ullage space. The cutoff frequency identified in Table II as TE 111 is doubly degenerate. The resonant line splits because of the differing sensitivity of the two polarizations. The horizontal E field TE 11 mode is much less sensitive to level changes in a nearly full or empty tank than the vertical E field TE lll. The mode identified as the TM 011 also shows good sensitivity near full and empty whereas the TM 010 does not. The TM 011 and TE 111 mode frequencies are shown as a function of liquid volume in figure 1. The volume is shown as volume per unit length since the precision of the measurement in $\frac{\circ}{0}$ is independent of tank length provided the tank is horizontal.

The limiting slope of the TE 111 and TM 011 modes as the tank approaches full and empty are given in Table III. 
Table II. Frequency as a function of kerosene volume in a horizontal $28.5 \mathrm{~cm}$ diameter by $32.7 \mathrm{~cm}$ long cylindrical tank.

\begin{tabular}{|c|c|c|c|c|c|c|}
\hline $\begin{array}{l}\text { Volume } \\
\text { per cm } \\
\text { length }\end{array}$ & $\begin{array}{l}\text { TE lll } \\
\text { E field } \\
\text { Vertical }\end{array}$ & $\begin{array}{l}\text { TE lll } \\
\text { E field } \\
\text { Horizontal }\end{array}$ & $\mathrm{TM} 010$ & TM 011 & & \\
\hline $\begin{array}{r}0 \\
8.13 \\
14.98 \\
28.07 \\
53.97 \\
83.07 \\
129.27 \\
170.19 \\
227.29 \\
284.52 \\
334.19 \\
383.95 \\
445.59 \\
491.97 \\
523.65 \\
564.41 \\
590.69 \\
615.23 \\
625.33 \\
633.20 \\
641.53\end{array}$ & $\begin{array}{l}768.3 \mathrm{MHz} \\
765.3 \\
762.6 \\
758.2 \\
747.8 \\
731.5 \\
709.0 \\
686.1 \\
657.5 \\
633.3 \\
614.4 \\
598.9 \\
580.0 \\
569.05 \\
560.9 \\
551.2 \\
541.1 \\
536.3 \\
533.6 \\
531.1 \\
530.0\end{array}$ & $\begin{array}{l}771.2 \\
771.1 \\
770.5 \\
769.2 \\
764.1 \\
749.5 \\
722.5 \\
690.9 \\
650.2 \\
617.4 \\
594.0 \\
574.7 \\
557.0 \\
547.5 \\
540.9 \\
535.2 \\
533.1 \\
531.9 \\
531.7 \\
531.1 \\
530.0\end{array}$ & $\begin{array}{l}804.7 \\
804.8 \\
804.6 \\
803.85 \\
799.9 \\
788.4 \\
763.6 \\
730.8 \\
685.6 \\
649.0 \\
621.3 \\
601.0 \\
569.05 \\
563.2 \\
560.0 \\
558.5 \\
557.9 \\
557.8 \\
557.9 \\
557.6\end{array}$ & $\begin{array}{l}927.3 \\
926.1 \\
925.0 \\
922.0 \\
913.6 \\
895.75 \\
864.4 \\
836.1 \\
794.0 \\
758.6 \\
730.0 \\
706.3 \\
682.2 \\
669.8 \\
660.8 \\
652.8 \\
648.9 \\
645.9 \\
644.8 \\
643.8 \\
643.4\end{array}$ & $\begin{array}{l}998.0 \\
977.4 \\
938.8 \\
909.0 \\
890.0 \\
873.75 \\
851.9 \\
841.1 \\
828.8 \\
796.1 \\
787.1 \\
775.7\end{array}$ & $\begin{array}{l}982.0 \\
963.1 \\
941.8 \\
915.1 \\
887.5 \\
853.8 \\
880.1 \\
812.0 \\
799.2 \\
785.0 \\
779.3 \\
774.4 \\
772.0\end{array}$ \\
\hline
\end{tabular}

The volume in the first column is given per unit length of the tank. Only frequencies below $1000 \mathrm{MHz}$ for the lowest six resonances were measured. The upper two are not identified. Note that only the TE 111 mode with a vertical E field and the TM Oll mode show significant level dependence near full and empty. The two TE III modes merge as the tank is approaches full. 


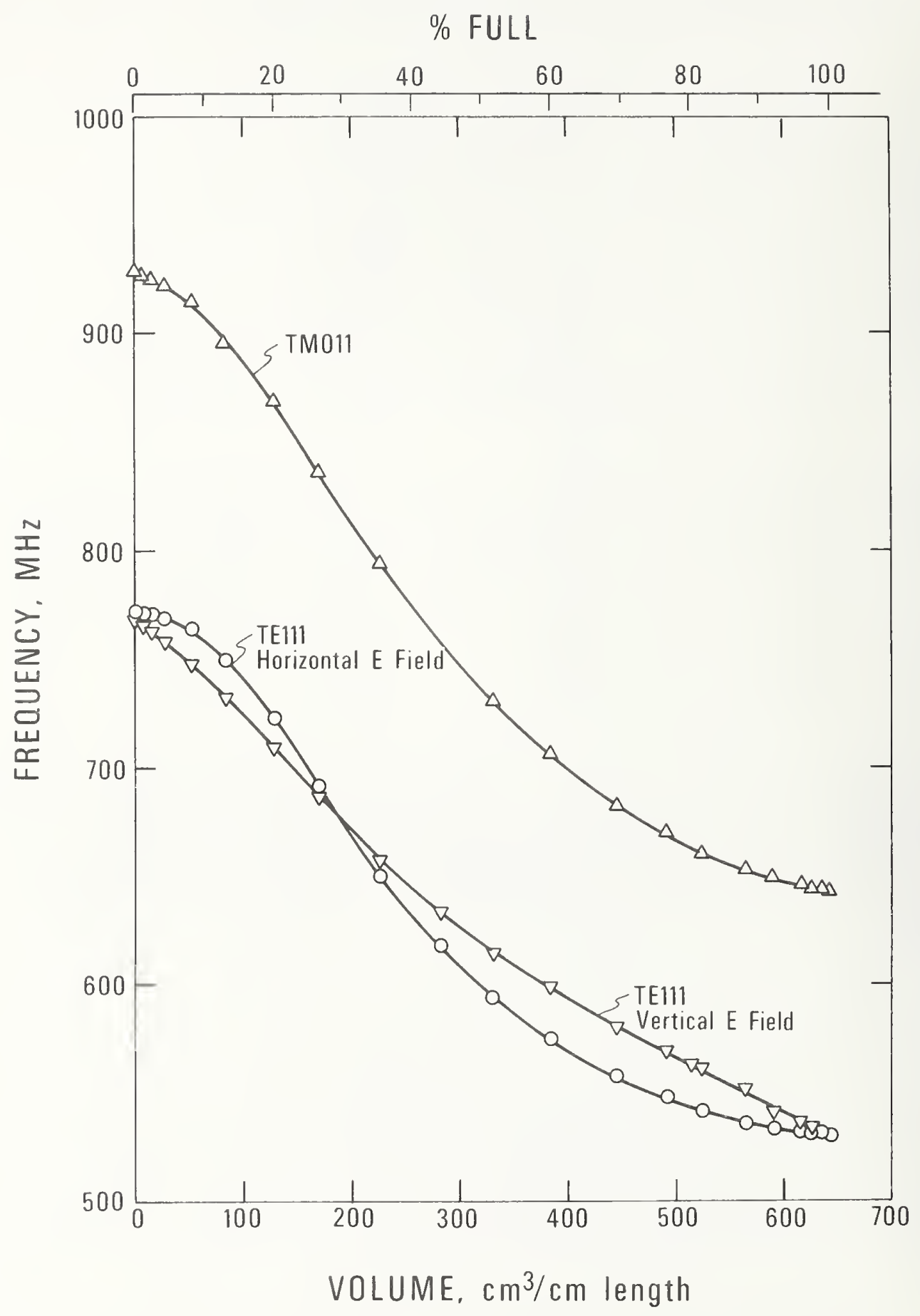

Figure 1. Resonant frequencies of selected modes as a function of liquid level in a horizontal cylindrical tank. 
Mode

TE 111

TM 011
$\Delta f$ per $\%$ change in kerosene volume approaching full approaching empty
$1.8 \mathrm{MHZ} / \%$

$.77 \mathrm{MHZ} / \%$
$2.4 \mathrm{MHz} / \%$

$1.0 \mathrm{MHz} / \%$

If this model were sealed up to the diameter of the tank car discussed above the slopes in table III are reduced by the ratio of the diameters which is 0.144. Assuming $Q$ is still 1600 and the uncertainty in the resonant line frequency measurement is no more than $1 / 5$ th the line width, then the line frequency can be measured to one part in 8000 . Since propane is the fluid of interest, the change in frequency between empty and full, hence the slopes in table III, are reduced by the factor: ( $\left.\varepsilon_{\text {propane }} / \varepsilon_{\text {kerosene }}\right)^{1 / 2}$ or 0.873 . The volume resolution of an rf gauage as this scaled up tank approaches empty is given by

$$
\Delta V\left(\frac{\circ}{\circ}\right)=(0.873 \times 0.144 \mathrm{~S})^{-1}(\mathrm{f} / 5 \mathrm{Q})=(.001) \mathrm{f} / \mathrm{S}
$$

where $\mathrm{S}$ is the slope given in table III and $f$ is the resonant frequency. For the TE $11 \mathrm{l}$ vertical mode near empty $\Delta V=0.04 \%$. As the propane level approaches full, $\mathrm{f}$ decreases by $1 / \sqrt{\varepsilon}$ which compensates for the decrease of $\mathrm{S}$ in table III and the resolution, $\Delta V$, remains $0.04 \%$. This resolution is equivalent to $+50 \mathrm{l}$ ( $+13 \mathrm{gal}$ ) uncertainty in a measurement of the contents of a $1.2510^{5} \mathrm{~L}(33,000 \bar{g} a l$.$) propane tank car. The resolution attainable$ with the TM 011 mode near full and empty is somewhat less than half that of the TE 111 mode. An antenna configuration that does not excite the horizontal TE lll mode is desirable if the TE lll mode is used for gauging.

How well this resolution can be translated into gauging accuracy depends on how accurately the gauge is calibrated and how well temperature changes are taken into account. Temperature changes effect the resonant frequency both through changes in tank size and change in liquid dielectric constant due to density changes. If the dielectric constant varies from carload to carload, this variation must be included also.

\section{CONCLUSIONS}

Measurements of the rf resonant modes of an empty tank car along with some measurements of resonant frequencies as a function of liquid levels indicate that tank car contents could be measured to a $\Delta V / V$, of better than $0.1 \%$ if the fluid dielectric constant is known, the tank is isothermal and the size is known. When the temperature varies during the course of the flame test measurement, errors are introduced. First, the tank expands, thereby decreasing the resonant frequencies of the empty tank. This error amounts to about $1 \%$ at the very high temperatures found on the shell above the liquid but might be corrected if tank wall temperatures are recorded. An additional error is introduced by heating the fluid. the dielectric constant, $\varepsilon$, changes approximately according to $(\varepsilon-1) /(\varepsilon+2)=\rho C_{m}$ where $\rho$ is the density and $C_{m}$ is a constant. This equation is linear to about 1\% over the density range encountered in the tests. A correction can again be applied by using temperature data.

The magnitude of the uncertainty of the mass of liquid remaining in the. tank has been estimated to be about 5\% for the case of a spherical tank containing two phase fluids [2]. Temperature data might again be used to reduce this uncertainty. However, further study of density change effects and correction methods are required to determine what gauging accuracy is obtainable under conditions existing during fire tests. 


\section{ACKNOWLEDGMENTS}

The author wishes to thank R. S. Collier for suggesting the rf measurements in a tank car and the Denver and Rio Grande Western Railroad Company for making their tank car Number AX 5230 available for rf measurements. The author wishes to thank especially Frank Robinson and Robert Guerrieri of that company for making the necessary arrangements.

6. REFERENCES

[1] Railroad Tank Car Safety Research and Test Project, Report RA-11-6-31 (AAA R-201) and RPI/AAR Technical Progress Report (Dec. 12, 1975).

[2] Collier, R.S., Ellerbruch, D., Cruz, J.E., Stokes, R. W., Luft, P.E., Peterson, R. G., and Hiester, A.E., Mass Quantity Gauging by RF Mode Analysis, NBSIR 73-318 (June 1973).

[3] Barrow, W.I. and Mieher, W.W., Natural Oscillations of Electrical Cavity Resonators, Proc. IRE 28, 184 (1940). 


\section{APPENDIX 1 \\ Resonance Frequency Measurements of Model Tank Car}

A cylindrical stainless steel tank $1.65 \mathrm{~cm}$ long by $30.094 \mathrm{~cm}$ ID was used to model a tank car. This would model a tank $2.44 \mathrm{~m}$ ( 8 ft) in diameter by $13.41 \mathrm{~m}$ (44 ft) long. A $3.8 \mathrm{~cm}$ diameter hole was cut in the tank about $4 \mathrm{~cm}$ from the half way point between the ends. The hole was shifted slightly from the center because a welded seam interferred. An open end of the tank was closed by bolting an aluminum plate over it. This cover made relatively poor electrical contact apparently, because pressing against the plate would slightly shift some mode frequencies.

The coupling to the cavity -was achieved with a loop antenna of about $3 \mathrm{~cm}^{2}$ placed through the hole so the plane of the loop was perpendicular to the centerline of the cylinder. Some mode degeneracies were apparently removed, i.e., resonance lines separated, by placing the plane of the loop parallel to the centerline because six additional resonances were observed, all near lines measured with a perpendicular antenna placement.

The experimental resonance frequencies are compared to calculated frequencies in the first 3 columns of table III. The experimental results are about $0.2 \%$ high at lower frequencies, essentially agree at the intermediate frequencies and lower or higher by as much as $0.4 \%$ at high frequencies. Some of the disagreement could be due to the poorly contacting flange cover.

Most tank cars have an approximately $2.5 \mathrm{~cm}$ diameter valve stem running vertically across the tank diameter from a point inside the dome. This was modeled in this tank by a 10-32 threaded rod on a diameter pressing against the top and bottom of the tank about one cm from the antenna hole. The presence of this rod reduced the TE 111 mode frequency by about $1 / 2 \%$ and added a trace of the TE 112 and strong lines at 667.5 and $763.8 \mathrm{MHz}$. The other mode lines were present and sometimes shifted by a few tenths of a percent. These results are shown in the fourth column of table III.

If a tank car should be measured while being filled with diesel oil, then the fill pipe would be inserted through the top with the end near the bottom of the car. This was modeled with an aluminum strip about $1 \mathrm{~cm}$ wide extending about $23 \mathrm{~cm}$ into the tank but grounded at the edge of the hole. The identified modes, with a couple of exceptions, were not significantly altered as shown in column 5, table III. The unidentified lines in column 4 have all been shifted.

For the most part, no TM modes were observed with the coupling used, though there was a little of the TM 011 mode observable after the valve stem was added. The other unidentified modes could also be shifted TM modes. 
Table IV. Resonant frequencies of a model tank car in MHz.

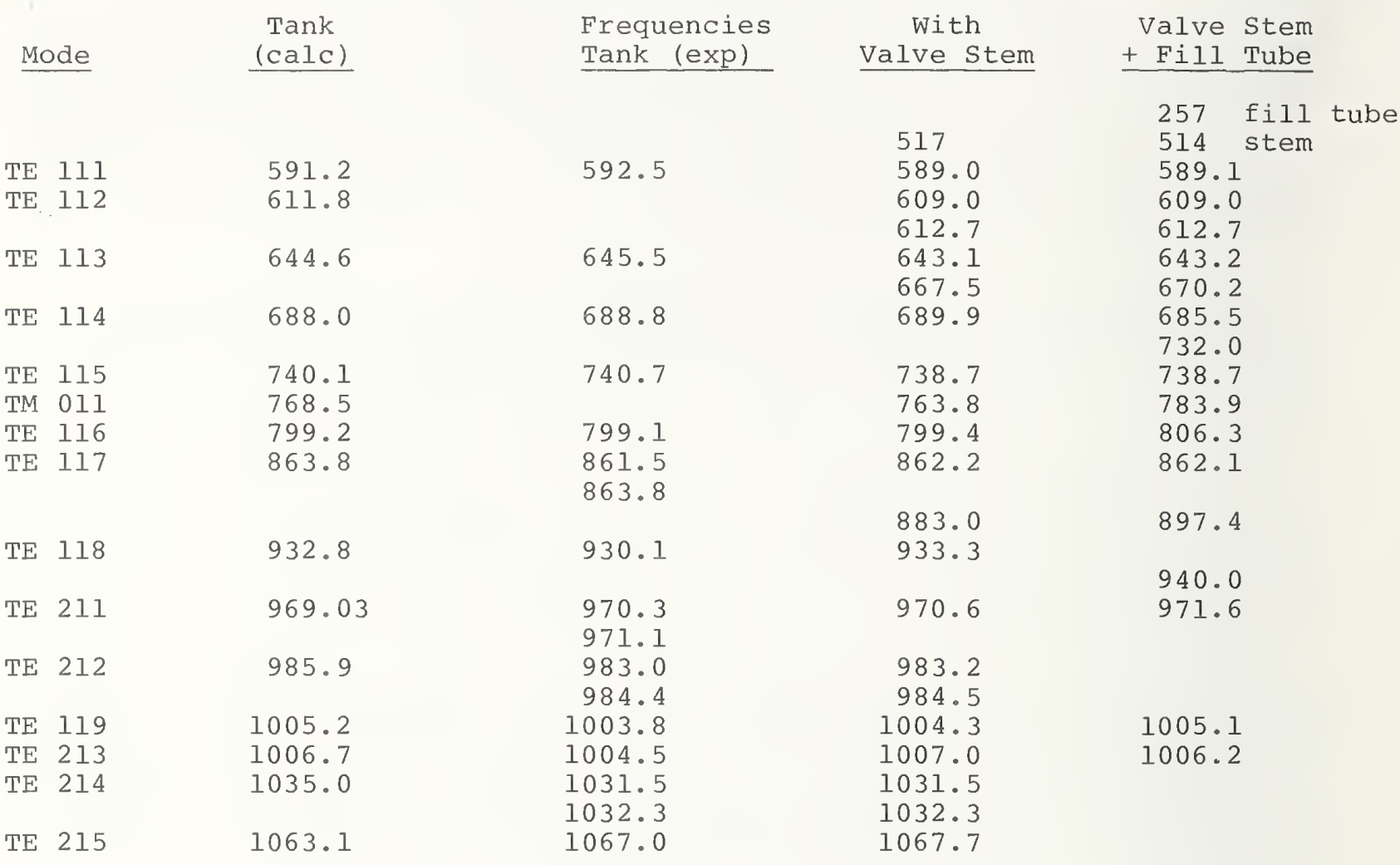

The modes and the calculated frequencies for an ideal cylinder of the model dimensions are given in the first two columns. The experimental mode frequencies are given in the third column. The TM 011 was not excited in the simple tank, but some line-splitting occurs in the higher modes. The experimental resonance lines measured in the tank car model show effects of the value stem and the value stem plus a fill tube in the 4 th and 5th columns respectively. The simulated valve stem and fill tubes did shift resonances slightly and introduce or delete a few other resonances. 
NBS-114A (REV.7-73)

\begin{tabular}{|c|c|c|}
\hline $\begin{array}{l}\text { 1. PUBLICATION OR REPORT NO. } \\
\text { NBSIR 79-1600 }\end{array}$ & $\begin{array}{l}\text { 2. Gov't Accession } \\
\text { No. }\end{array}$ & 3. Recipient's Accession No. \\
\hline \multirow{2}{*}{\multicolumn{2}{|c|}{$\begin{array}{l}\text { 4. TITLE AND SUBTITLE } \\
\text { RADIO FREQUENCY LIQUID LEVEL GAUGING IN PROPANE TANK } \\
\text { CAR SAFETY TESTS - A FEASIBILITY STUDY }\end{array}$}} & $\begin{array}{l}\text { 5. Publication Date } \\
\text { January } 1979\end{array}$ \\
\hline & & $\begin{array}{l}\text { 6. Performing Organization Code } \\
736\end{array}$ \\
\hline \multicolumn{2}{|l|}{$\begin{array}{l}\text { 7. AUTHOR(S) } \\
\text { J. D. Siegwarth }\end{array}$} & 8. Performing Organ. Report No. \\
\hline \multicolumn{2}{|l|}{$\begin{array}{l}\text { 9. PERFORMING ORGANIZATION NAME AND ADDRESS } \\
\text { NATIONAL BUREAU OF STANDARDS } \\
\text { DEPARTMENT OF COMMERCE } \\
\text { WASHINGTON, D.C. } 20234\end{array}$} & $\begin{array}{l}\text { 10. Project/Task/Work Untt No. } \\
\frac{7360460}{\text { 11. Contract/Grant No. }}\end{array}$ \\
\hline \multirow{2}{*}{\multicolumn{2}{|c|}{ 12. Sponsoring Organization Name and Complete Address (Street, City, State, ZIP) }} & $\begin{array}{l}\text { 13. Type of Report \& Period } \\
\text { Covered }\end{array}$ \\
\hline & & 14. Sponsoring Agency Code \\
\hline
\end{tabular}

15. SUPPI.EMENTARY NOTES

16. ABSTRACT (A 200-word or less factual summary of most significant information. If document includes a significant bibliography or literature survey, mention it here.)

Selected radio frequency ( $r f$ ) resonances of an empty 30,300 liter ( 3,000 gallon) tank car have been measured to determine whether rf can be used to gauge the propane liquid levels during tank car fire safety tests. The change of resonant frequencies of a small horizontal cylindrical tank as a function of liquid volume has been tested in order to estimate the precision to which the amount of propane in a tank car can be measured. The technique is applicable to routine tank car gauging.

17. KEY WORDS (six to twelve entries; alphabetical order; capitalize only the first letter of the first key word unless a proper name; separated by semicolons)

Level gauging; propane; radio frequency

$$
1
$$

$$
\text { X Unlimited }
$$

For Official Distribution. Do Not Release to NTIS

Order From Sup. of Doc., U.S. Government Printing Office Washington, D.C. 20402, SD Cat. No. C13

X Order From National Technical Information Service (NTIS) Springfield, Virginia 22151

\begin{tabular}{|l|c|}
\hline $\begin{array}{l}\text { 19. SECURITY CLASS } \\
\text { (THIS REPURT) }\end{array}$ & 16 \\
UNCL ASSIFIED & 16 NO. OF PAGES \\
\hline $\begin{array}{l}\text { 20. SECURITY CLASS } \\
\text { (THIS PAGE) }\end{array}$ & 22. Price \\
UNCLASSIFIED & 3.00 \\
\hline
\end{tabular}





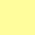


